\title{
Studi Komparasi Sistem Steel Frame Tube dengan Sistem Steel Braced Tube menggunakan X-Brace
}

\author{
Comparisson Study of Steel Frame Tube System with Steel Braced \\ Tube System using X-Brace
}

\author{
Gabriella Junico $^{1, a)} \&$ Lidya Fransisca Tjong ${ }^{1, b)}$ \\ ${ }^{1)}$ Program Studi Teknik Sipil, Fakultas Teknik, Universitas Katolik Parahyangan, Bandung
}

Koresponden : ${ }^{a}$ junicogabriella@gmail.com \& ${ }^{b)}$ lidyafransiscatjong@ gmail.com

\begin{abstract}
ABSTRAK
Sistem tabung merupakan sistem yang umum digunakan dalam struktur bangunan tinggi, seperti Sistem Steel Frame Tube (SFT). Akan tetapi karena fenomena shear lag, distribusi tegangan aksial pada kolom-kolom perimeter sudut menjadi lebih besar dibandingkan dengan kolom perimeter lainnya. Hal ini ditanggulangi dengan menggunakan Sistem Steel Braced Tube (SBT) yang dapat membuat perimeter gedung menjadi lebih kaku dengan menggunakan diagonal pada seluruh muka gedung. Studi ini meneliti respons elastik dan inelastik dari gedung 12 lantai menggunakan kedua sistem struktur tersebut dengan analisis respons spektrum dan riwayat waktu menggunakan rekaman percepatan gempa El-Centro 1940, Kobe 1995, dan Denpasar 1979. Berdasarkan hasil analisis respons spektrum, kekakuan pada Sistem SBT lebih tinggi sehingga peralihan lantai dan simpangan antar lantai pada sistem tersebut menjadi lebih kecil. Berdasarkan hasil analisis riwayat waktu, saat kondisi inelastik peralihan lantai dan simpangan antar lantai pada Sistem SFT juga bernilai lebih besar untuk ketiga rekaman percepatan gempa. Elemen breising pada Sistem SBT mengalami kelelehan terlebih dahulu dibandingkan elemen lain karena breising ditetapkan sebagai elemen fuse. Kedua sistem struktur memiliki tingkat kinerja Immediately Occupancy (IO). Dari hasil analisis dapat disimpulkan bahwa selain mengurangi fenomena shear lag, Sistem SBT memiliki respons elastik dan inelastik yang lebih baik.
\end{abstract}

Kata Kunci : manajemen fasilitas, analisis respons spektrum, analisis riwayat waktu, shear lag, steel braced tube, steel frame tube

\section{PENDAHULUAN}

Perancangan Infrastruktur \& Fasilitas merupakan bagian penting bagi Manajemen Aset Infrastruktur \& Fasilitas. Setiap jenis konstruksi mempunyai kekhasan permasalahan yang berbeda-beda. Hal ini akan mengakibatkan solusi yang berbeda. (Suprayitno \& Soemitro, 2018). Suatu gedung bisa saja mempunyai iregularitas horizontal. Solusi menghadapi hal ini dengan menggunakan base isolation dan fixed base telah dipelajari (Arifin dkk., 2019). Pada suatu gedung bertingkat rangka baja, terutama di Indonesia di mana beban lateral yang dihasilkan oleh gempa sangat penting, berbagai teknik solusi perlu dikaji dengan baik.

Dalam mendesain struktur gedung bertingkat, sistem penahan beban lateral seperti beban gempa menjadi hal yang penting. Semakin tinggi bangunan berdiri, maka simpangan lateral akan semakin besar (Reddy \& Eadukondalu, 2018). Menurut Badan Meteorologi Klimatologi dan Geofisika (BMKG), Indonesia juga merupakan negara dengan tingkat kegempaan yang cukup tinggi. Oleh karena itu, pembangunan struktur gedung bertingkat di Indonesia harus memenuhi standar ketahanan gempa yang berlaku. 
Salah satu sistem penahan beban lateral yang umum digunakan adalah Sistem Steel Frame Tube (SFT). Sistem ini dapat didefinisikan sebagai sistem tiga dimensi yang memanfaatkan seluruh perimeter bangunan untuk menahan beban lateral sehingga pada bagian interior bangunan hanya dialokasikan untuk menahan beban gravitasi. Persyaratan yang diperlukan untuk membuat sistem tersebut menjadi seperti tabung adalah dengan menempatkan kolom perimeter dengan jarak antar kolom yang relatif berdekatan dan menggunakan spandrel dengan sambungan momen sebagai penghubung antar kolom. Pada gedung bertingkat, jarak antar kolom yang saling bedekatan memberi pengaruh terhadap arsitektural facade, pandangan keluar gedung pun menjadi terbatas. Selain itu karena fleksibilitas dari spandrel, fenomena shear lag dapat terjadi pada distribusi tegangan aksial saat terjadi momen lentur. Karena fenomena tersebut, dikembangkan Sistem Steel Braced Tube (SBT) yaitu sistem tabung dengan diagonal pada bagian facade yang dapat mengurangi jumlah kolom perimeter pada Sistem SFT. Diagonal pada sistem tersebut memperkaku bagian perimeter sehingga dapat mengurangi fenomena shear lag. Sistem SBT juga memanfaatkan bagian perimeter gedung untuk menahan beban lateral dan pada bagian interior gedung digunakan untuk menahan beban gravitasi.

Penelitian ini bertujuan untuk mengetahui perbedaan perilaku struktur dan efek shear lag dari gedung bertingkat akibat beban lateral gempa pada Sistem SFT dan Sistem SBT dengan metode analisis statik ekuivalen, respons spektrum, dan riwayat waktu.

\section{STUDI PUSTAKA}

\section{Sistem Steel Frame Tube (SFT)}

Pengembangan ide dari Sistem Steel Frame Tube adalah membuat sistem struktur tiga dimensi yang mengikutsertakan inersia dari perimeter gedung untuk menahan beban lateral. Sistem ini merupakan sistem tabung yang menggunakan kolom eksterior dengan jarak antar kolom yang relatif berdekatan dan menggunakan spandrel yang menerus disepanjang perimeter gedung pada setiap sisi dengan sambungan rigid sebagai penghubung antar kolom, seperti Gambar 1. Berdasarkan ketentuan tersebut, sistem ini dapat berperilaku seperti tabung kantilever yang terjepit di tanah. Persyaratan jarak antar kolom berkisar antara $10 \mathrm{ft}(3,05 \mathrm{~m})$ hingga $15 \mathrm{ft}$ (4,60 m) (Taranath, 2017).

Pada sistem ini, sisi gedung yang tegak lurus dengan arah datang gaya lateral disebut flange dan sisi gedung yang sejajar dengan arah datang gaya lateral disebut web. Saat gedung mengalami momen akibat gaya lateral, kolom pada bagian flange akan mengalami gaya tarik dan tekan. Sedangkan pada bagian web akan mengalami inplane bending (Taranath, 2017) seperti yang dapat dilihat pada Gambar 2.
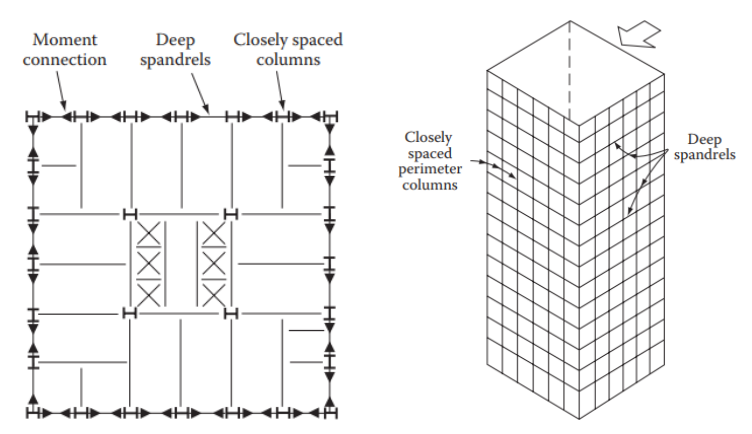

Gambar 1. Denah dan Isometrik Gedung pada Sistem Steel Frame Tube (sumber: Taranath, 2012)

Karena dibuat menyerupai tabung, distribusi tegangan aksial kolom perimeter pada Sistem SFT dapat diketahui. Semakin distribusi tegangan aksial tersebut menyerupai distribusi tegangan aksial dari tabung kantilever rigid, semakin efektif sistem tersebut bekerja. Saat 
gedung terkena beban lateral terjadi beam-column frame yaitu komponen struktur mengalami gaya lateral seperti balok dan gaya tekan seperti kolom (Taranath, 2017).

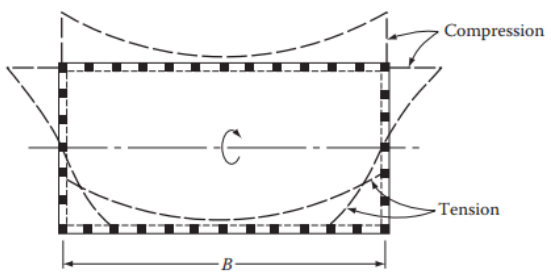

(a)

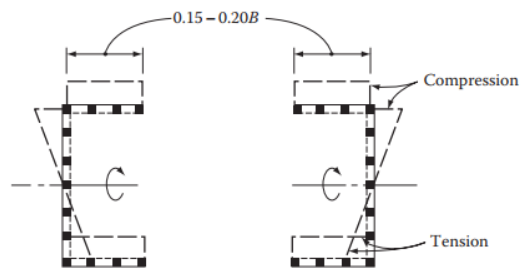

(b)

Gambar 2. Framed Tube: (a) Distribusi Tegangan Aksial dengan Efek Shear Lag dan (b) Distribusi Tegangan Aksial Tanpa Efek Shear Lag (sumber: Taranath, 2017)

Deformasi aksial dari frame tersebut menyebabkan terjadi aksial dan lentur pada setiap elemen serta rotasi pada setiap pertemuan antar elemen. Hal ini mengakibatkan berkurangnya kekakuan efektif dari Sistem SFT yang dapat menyebabkan terjadinya efek shear lag. Secara umum, kolom perimeter bagian tengah akan menerima distribusi tegangan aksial yang lebih kecil dibandingkan kolom sudut. Efisiensi dari Sistem SFT bergantung pada rasio perbandingan tinggi dan lebar bangunan, dimensi dari denah bangunan, serta spasi dan ukuran dari kolom dan spandrel. Karena fenomea shear lag tidak dapat terhindarkan, prinsip utama untuk mendesain gedung dengan menggunakan Sistem SFT adalah mengurangi efek shear lag (Taranath, 2017).

\section{Sistem Steel Braced Tube (SBT)}

Jarak antar kolom yang relatif berdekatan memberikan dampak yang signifikan terhadap arsitektural façade. Oleh karena itu dikembangkan suatu sistem tabung lain yaitu Sistem Steel Braced Tube yang dapat memperluas pandangan ke luar gedung. Sistem ini dapat dikatakan berperilaku seperti tabung karena menggunakan diagonal pada setiap sisi gedung yang berpotongan dengan kolom sudut. Agar dapat berperilaku secara efektif, kolom diganti dengan breising diagonal pada kedua arah (Taranath, 2012) seperti pada Gambar 3.

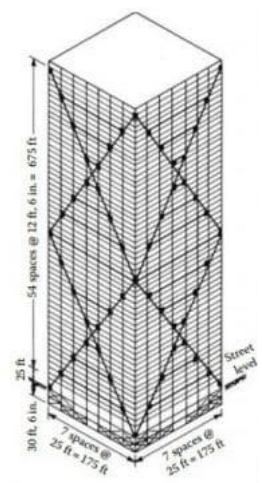

Gambar 3. Sistem Steel Braced Tube (sumber: Taranath, 2012)

Karena breising diagonal pada masing-masing sisi gedung saling bertemu dengan kolom sudut, efek shear lag dapat terkurangi pada bagian flange maupun web. Struktur berperilaku seperti rangka breising yang membuat momen pada bagian kolom dan balok eksterior menjadi berkurang. Gaya geser juga lebih dominan ditahan oleh breising diagonal dibandingkan dengan spandrel. Breising diagonal menahan gaya lateral secara dominan pada gaya aksial dan membuat gedung lebih bersifat rigid bersamaan dengan balok spandrel. Selain membuat jarak antar kolom ekterior menjadi lebih besar, penggunaan dimensi kolom eksterior dan spandrel juga menjadi lebih kecil jika dibandingkan dengan Sistem SFT (Taranath, 2012). 


\section{Analisis Statik Ekuivalen}

Metode analisis statik ekuivalen digunakan untuk menganalisis fenomena shear lag. Dengan metode ini dapat diperoleh distribusi gaya aksial pada kolom perimeter di kedua model. Pada analisis statis linear dan analisis dinamik linear, gaya lateral terdistribusikan ke semua elemen dan komponen struktur sesuai dengan karakteristik kekakuan elastis yang dimiliki (ASCE 41-17). Gaya yang terjadi pada struktur dapat ditentukan dengan metode analisis dinamik riwayat waktu, respons spektrum, atau dengan metode sederhana statik ekuivalen.

Pada metode analisis statik ekuivalen digunakan persamaan empiris untuk memperoleh gaya inersia yang didefinisikan sebagai gaya statik. Metode statik ekuivalen hanya dapat dilakukan untuk struktur gedung yang beraturan (regular). Gaya seismik pada setiap lantai merupakan bagian dari total gaya geser dasar (ASCE 41-17).

$$
\begin{aligned}
& F_{x}=C_{v x} V \\
& C_{v x}=\frac{w_{x} h_{x}{ }^{k}}{\sum_{i=1}^{n} w_{i} h_{i}{ }^{k}}
\end{aligned}
$$

\section{Keterangan:}

$$
\begin{aligned}
& w_{i}, w_{x}=\text { Bagian dari berat seismik efektif pada lantai ke-i atau } \mathrm{x} \\
& h_{i}, h_{x}=\text { Ketinggian di atas dasar pada lantai ke-i atau } \mathrm{x} \\
& k \\
& k=\text { Eksponen terkait dengan periode gedung }
\end{aligned}
$$

\section{Analisis Respons Spektrum}

Salah satu metode analisis linear terhadap beban gempa adalah analisis respons spektrum. Pada metode analisis respons spektrum, digunakan analisis dinamik pada model matematis suatu bangunan untuk membuat frekuensi modal dan bentuk ragam. Digunakan prosedur standar matematis dan respons spektrum yang sesuai dengan redaman pada bangunan. Frekuensi modal dan bentuk ragam digunakan untuk membuat kebutuhan spektral (spectral demand). Metode ini dapat digunakan untuk bangunan gedung yang tidak beraturan (irregular). Hasil dari analisis respons spektrum adalah respons struktur elastik seperti peralihan tiap lantai dan simpangan antar lantai, kekakuan dan gaya geser tingkat struktur, dan berbagai parameter lain yang dibutuhkan dalam melakukan analisis nonlinear (ASCE 41-17).

\section{Analisis Riwayat Waktu}

Analisis riwayat waktu merupakan metode analisis nonlinear terhadap beban gempa. Struktur diberikan percepatan pada permukaan tanah yang sesuai dengan rekaman percepatan gempa terhadap waktu yang diperoleh dari data riwayat waktu (ASCE 41-17). Dalam melakukan analisis riwayat waktu digunakan pendekatan umum integrasi langsung numerik dari persamaan keseimbangan dinamik untuk memperoleh respons dinamik dari sistem struktur.

Hasil dari metode integrasi langsung berkaitan dengan besarnya nilai dari selang waktu dalam melakukan analisis. Semakin kecil ukuran selang waktu, maka analisis akan semakin akurat akan tetapi mengakibatkan durasi analisis menjadi semakin lama. Hal ini dikarenakan dalam setiap selang waktu, terjadi pembentukan matriks kekakuan struktur dan diselesaikan kembali dengan persamaan integrasi (Jasinda, 2018).

Dalam analisis integrasi langsung dibutuhkan metode integrasi numerik terhadap waktu untuk mencapai penyelesaian. Salah satu metode yang dapat digunakan adalah metode integrasi waktu Wilson. Metode ini serupa dengan metode percepatan linear yang didasarkan pada asumsi bahwa percepatan bervariasi secara linear selama interval diperpanjang (Steeger, 2010).

Redaman Rayleigh digunakan untuk memodelkan respons dinamik struktur. Nilai redaman yang digunakan dalam analisis dinamik riwayat waktu proporsional terhadap kekakuan dan massa struktur, sedangkan nilai rasio redaman kritis digunakan dalam analisis modal adalah sebesar 5\% (Alipour \& Zareian, 2008). 
Saat struktur memasuki fase inelastis, terjadi perubahan kondisi struktur seperti pengurangan kekakuan elemen struktur dan timbul deformasi yang bersifat permanen. Salah satu indikasi elemen struktur mulai bersifat nonlinear adalah dengan terbentuknya sendi plastis. Sendi plastis terjadi ketika beban yang bekerja pada struktur melebihi kapasitas elastik elemen struktur (FEMA 356). Indikator warna dari sendi plastis dapat dilihat pada Gambar 4. Indikator warna tersebut merupakan batasan dari kondisi elemen struktur seperti pada Gambar 5.

Gambar 4. Indikator Sendi Plastis

Beban gempa dapat mengakibatkan kemungkinan gaya inersia yang terjadi melebihi kapasitas leleh elemen struktur pada suatu waktu tertentu. Kondisi ini akan mengakibatkan terjadinya kelelehan dan deformasi plastis pada elemen struktur tersebut (FEMA 356).

Pada studi ini digunakan tiga percepatan gempa, yaitu El-Centro 1940 dengan durasi 14 detik, Denpasar 1979 dengan durasi 16,5 detik, dan Kobe 1995 dengan durasi 30 detik. Rekaman percepatan gempa harus diskalakan sehingga kurva respons dari gempa tersebut dapat sesuai dengan respons spektrum wilayah yang digunakan.

\section{Tingkat Kinerja Struktur}

Tingkat kinerja struktur berdasarkan deformasi dapat ditinjau dalam dua cara, kinerja struktur secara global dan kinerja komponen struktur. Pada kinerja struktur secara global digunakan roof drift ratio, yaitu perbandingan perpindahan lantai atap dengan tinggi total gedung. Berdasarkan FEMA 356, batasan tingkat kinerja struktur menurut roof drift ratio dapat dilihat pada Tabel 1.

Tabel 1. Tingkat Kinerja Struktur Berdasarkan Roof Drift Ratio

\begin{tabular}{lcc}
\hline \multirow{2}{*}{ Tingkat Kinerja Struktur } & \multicolumn{2}{c}{ Roof Drift Ratio } \\
\cline { 2 - 3 } & Rangka Momen Baja & Rangka Breising Baja \\
\hline Immediately Occupancy (IO) & 0.007 & 0,005 \\
Life Safety (LS) & $0,010-0,025$ & 0,15 \\
Collapse Prevention (CP) & 0,05 & 0,02 \\
\hline
\end{tabular}

Tingkat kinerja bangunan berdasarkan kinerja komponen struktur dapat diklasifikasikan ke dalam 3 tingkat (FEMA 356), antara lain:

1. Immediate Occupancy (IO)

Pada tingkat ini, gedung yang rusak seteleh gempa aman untuk dihuni kembali, struktur masih memiliki kekuatan dan kekakuan seperti desain bangunan sebelum terkena gempa, dan hanya terjadi sedikit kerusakan struktural. Risiko yang mengancam keselamatan pengguna bangunan akibat kerusakan struktur sangat rendah.

2. Life Safety (LS)

Pada tingkat ini, komponen struktur gedung mengalami kerusakan yang terletak diantara kerusakan sebagian dan kerusakan total. Beberapa elemen struktur mengalami kerusakan parah dan beberapa elemen struktur lainnya tidak. Saat terjadi gempa bisa terdapat korban luka, tetapi secara keseluruhan risiko yang mengancam keselamatan pengguna rendah.

3. Collapse Prevention (CP)

Kerusakan setelah gempa berada diantara batas runtuh sebagian dan runtuh total. Ada kerusakan besar struktur, pengurangan kekuatan dan kekakuan yang signifikan terhadap sistem penahan gaya lateral, deformasi lateral permanen yang besar, dan pengurangan kapasitas menahan gaya vertikal. Risiko terdapatnya korban akibat keruntuhan struktur mungkin terjadi. Struktur tidak dapat diperbaiki dan tidak aman untuk dihuni kembali. 


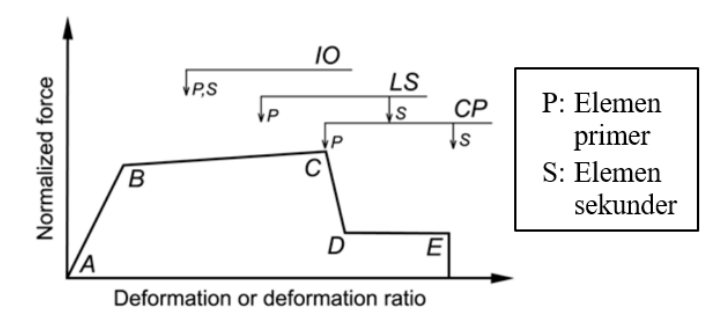

Gambar 5. Hubungan Gaya - Deformasi (sumber: FEMA 356, 2000)

\section{METODE PENELITIAN}

Pada penelitian ini, digunakan data struktur yang telah ditetapkan terlebih dahulu sebelum melakukan analisis. Berikut merupakan data struktur tersebut.

1. Lokasi gedung

2. Jenis tanah dasar

3. Kategori Desain Seismik

4. Fungsi gedung

5. Jumlah lantai

6. Tinggi antar lantai

7. Tinggi total gedung

8. Sistem struktur
: Jambi $\left(\mathrm{S}_{\mathrm{S}}=0,212 \mathrm{~g}\right.$ dan $\left.\mathrm{S}_{1}=0,171 \mathrm{~g}\right)$

: Tanah keras $\left(\mathrm{F}_{\mathrm{a}}=1,2\right.$ dan $\left.\mathrm{F}_{\mathrm{v}}=1,629\right)$

: $\mathrm{C}$

: Gedung apartemen $\left(\mathrm{I}_{\mathrm{e}}=1\right)$

$: 12$

: 4 meter

: 48 meter

: a. Rangka Baja Pemikul Momen Khusus

$\left(\mathrm{R}=8, \Omega_{0}=3\right.$, dan $\left.\mathrm{C}_{\mathrm{d}}=5,5\right)$

b. Rangka Baja dengan Breising Konsentrik Khusus $\left(\mathrm{R}=6, \Omega_{0}=2\right.$, dan $\left.\mathrm{C}_{\mathrm{d}}=5\right)$

Nilai $R, \Omega_{0}$, dan $C_{d}$ yang digunakan diperoleh dari peraturan kegempaan yang berlaku di Indonesia, yaitu SNI 1726:2012.

\section{Pemodelan Struktur}

Terdapat dua model gedung baja yang akan ditinjau yaitu gedung dengan Sistem Steel Frame Tube (SFT) dan dengan Sistem Steel Braced Tube (SBT). Kedua model memiliki denah, mutu material, dan profil elemen yang sama kecuali pada elemen breising seperti yang dapat dilihat pada Tabel 2. Profil yang digunakan harus memenuhi ketentuan yang terdapat dalam AISC 341-16 dan AISC 360-16. Kedua model menggunakan pembebanan yang sama sesuai dengan peraturan pembebanan SNI 1727:2013.

Tabel 2. Profil Elemen Struktur

\begin{tabular}{|c|c|c|}
\hline Elemen Struktural & Simbol & Profil \\
\hline Kolom Interior & $\mathrm{K}-1$ & HB 350x350x14x22 \\
\hline Kolom Interior & $\mathrm{K}-2$ & HB $400 \times 400 \times 30 \times 50$ \\
\hline Kolom Eks terior & $\mathrm{KP}$ & HSS $400 \times 25$ \\
\hline Kolom Sudut & KPC & HSS $400 \times 25$ \\
\hline Balok Induk Interior & $\mathrm{BI}$ & WF $700 \times 300 \times 13 \times 24$ \\
\hline Spandrel & $\mathrm{SP}$ & WF 500x200x10x16 \\
\hline Balok Anak & BA-1 & WF $300 \times 150 \times 5,5 \times 8$ \\
\hline Balok Anak & BA-2 & WF $600 \times 300 \times 14 \times 23$ \\
\hline Breising & $\mathrm{BR}$ & HSS 250x16 \\
\hline
\end{tabular}

Gedung 12 lantai berukuran 36x36 $\mathrm{m}^{2}$ dengan ketinggian antar lantai $4 \mathrm{~m}$. Jarak antar kolom perimeter gedung dengan Sistem SFT adalah 3 m seperti pada Gambar 6. Gedung dengan 
Sistem SBT menggunakan breising konfigurasi X pada setiap muka gedung dengan jarak antar kolom perimeter $6 \mathrm{~m}$ seperti pada Gambar 7. Elemen struktural pada kedua sistem menggunakan profil WF dan profil H-Beam yang mengacu pada profil Japanese Industrial Standard (JIS), sedangkan profil HSS mengacu pada profil Gunung Garuda.

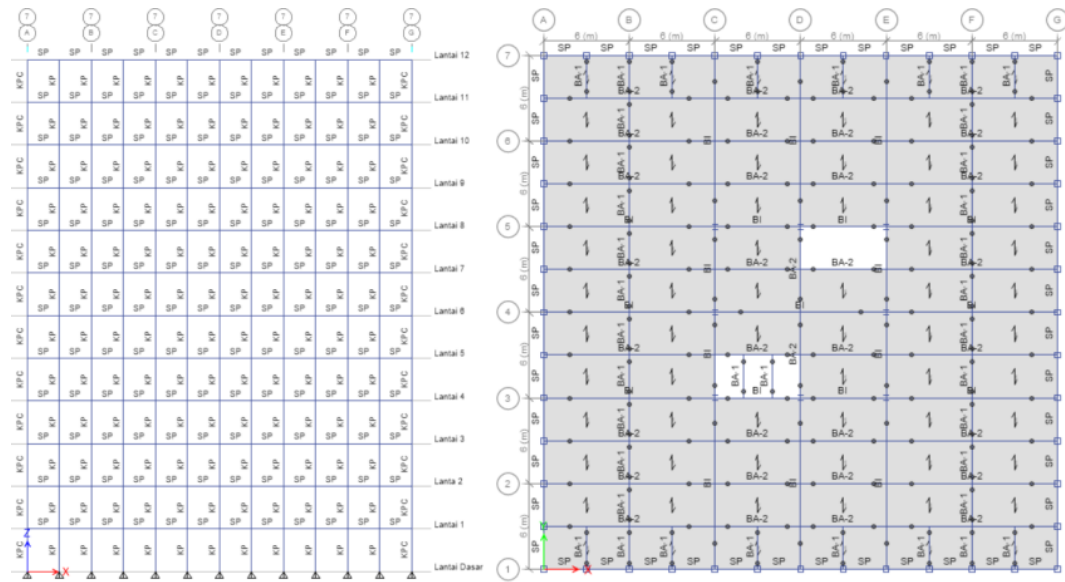

Gambar 6. Tampak Perimeter dan Denah Gedung pada Sistem Steel Frame Tube

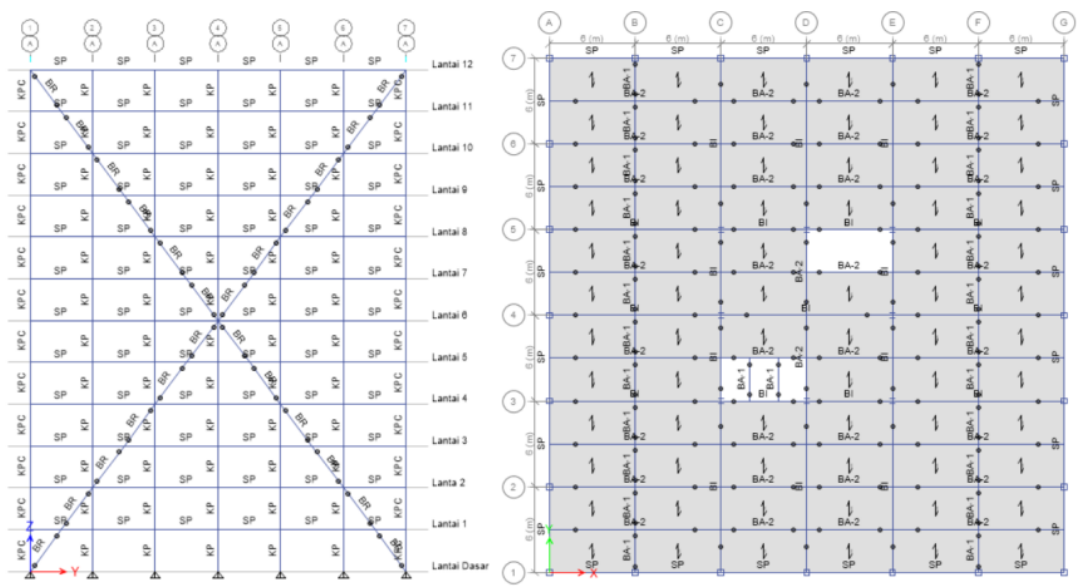

Gambar 7. Tampak Perimeter dan Denah Gedung pada Sistem Steel Braced Tube

\section{ANALISIS PENELITIAN}

\section{Analisis Efek Shear Lag Menggunakan Metode Statik Ekuivalen}

Dari hasil analisis shear lag pada lantai 1, 6, dan 12 Sistem Steel Frame Tube, disimpulkan bahwa gaya aksial terbesar pada kolom sudut berada pada lantai 1 seperti yang dapat dilihat pada Gambar 8 sampai dengan Gambar 10. 


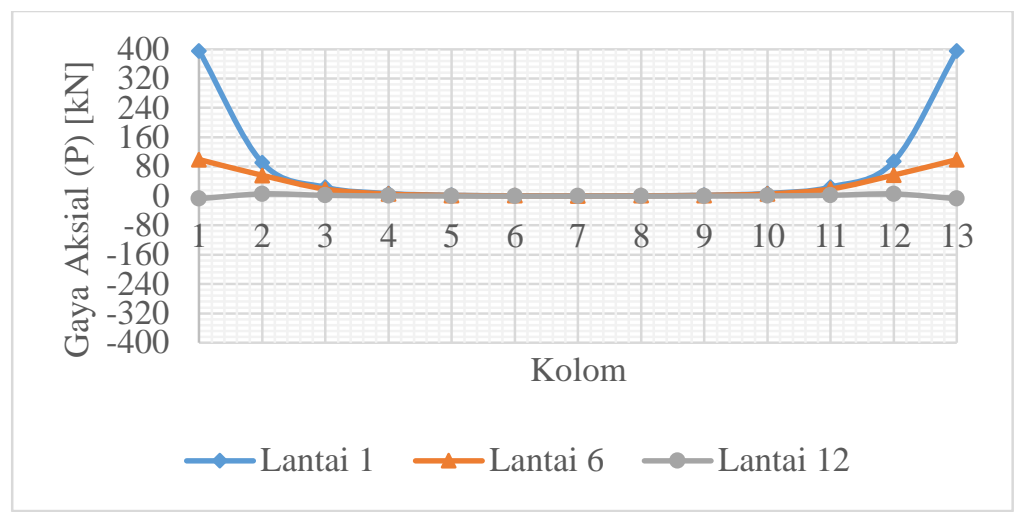

Gambar 8. Distribusi Gaya Aksial pada Kolom Perimeter SFT di Potongan A

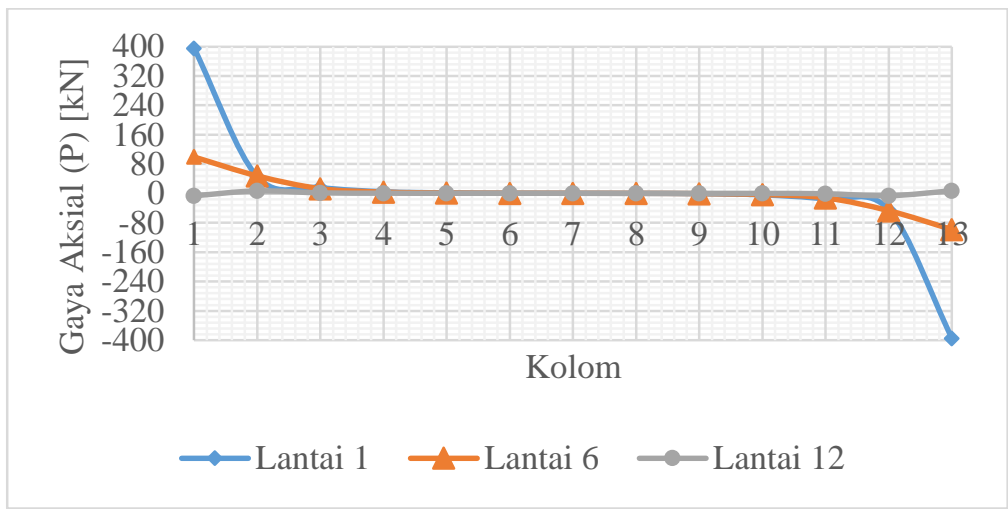

Gambar 9. Distribusi Gaya Aksial pada Kolom Perimeter SFT di Potongan 1 dan 7

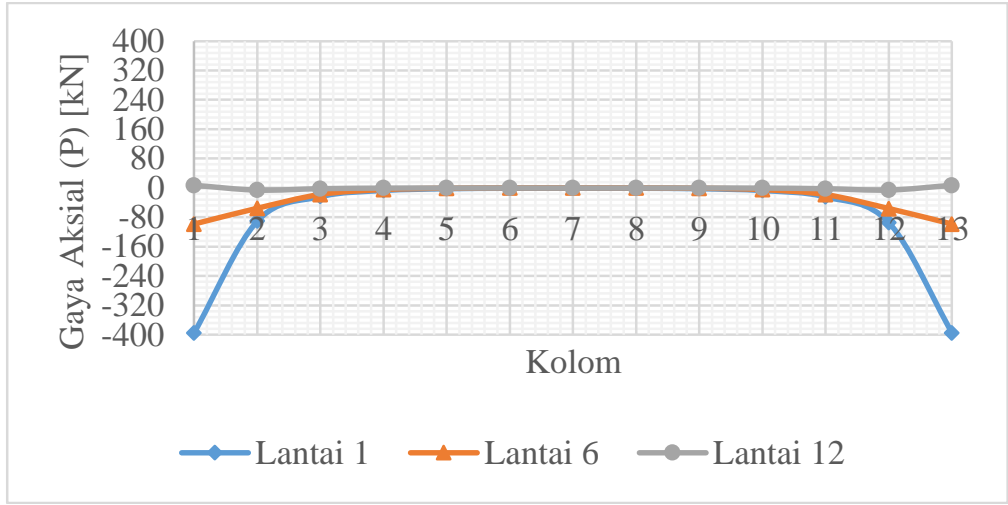

Gambar 10. Distribusi Gaya Aksial pada Kolom Perimeter SFT di Potongan G

Gaya aksial tersebut akan mengalami penurunan seiring dengan bertambahnya ketinggian lantai dan semakin mendekati gaya aksial pada kolom perimeter diantaranya. Oleh karena itu, dilakukan analisis perbandingan efek shear lag pada Sistem Steel Frame Tube dan Sistem Steel Braced Tube pada lantai 1.

\section{Perbandingan Gaya Aksial pada Model SFT dan Model SBT}

Fenomena shear lag memang dapat berkurang apabila digunakan breising pada bagian perimeter gedung. Akan tetapi penggunaan breising mengakibatkan reaksi pada tumpuan kolom-kolom perimeter sudut menjadi lebih besar. Hal ini dikarenakan gaya aksial yang bekerja pada breising ditahan oleh tumpuan pada kolom perimeter sudut. Distribusi gaya aksial pada kolom-kolom perimeter Sistem SFT dan Sistem SBT dapat dilihat pada Gambar 11 sampai dengan Gambar 13. 


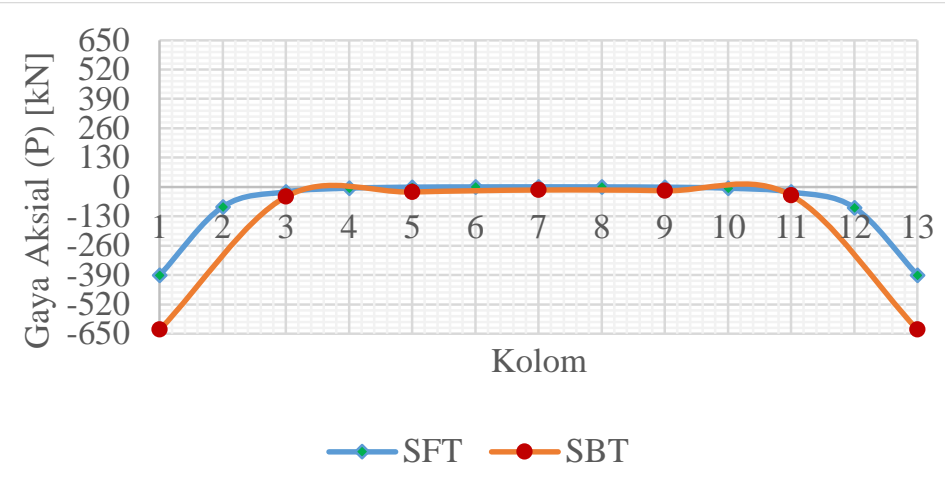

Gambar 11. Komparasi Distribusi Gaya Aksial Model SFT dan SBT pada Potongan A

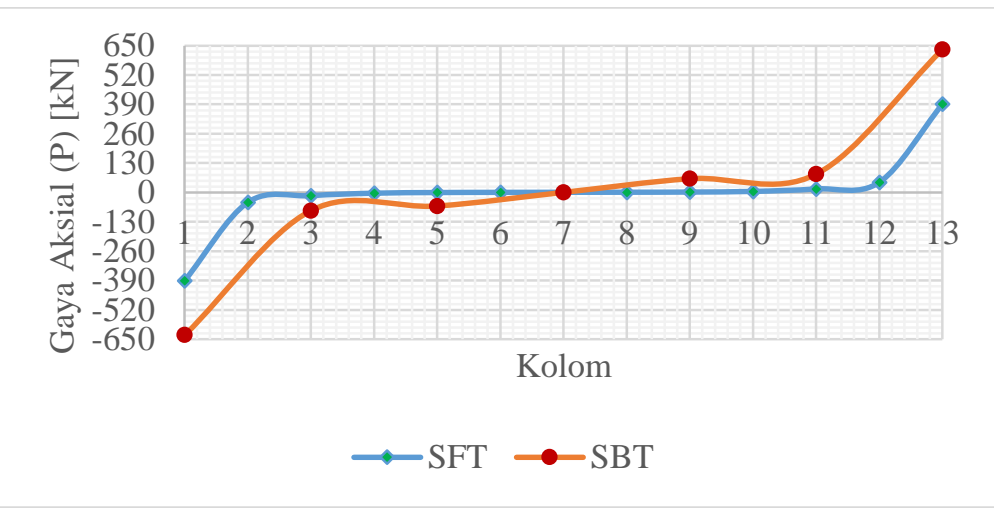

Gambar 12. Komparasi Distribusi Gaya Aksial Model SFT dan SBT pada Potongan 1,7

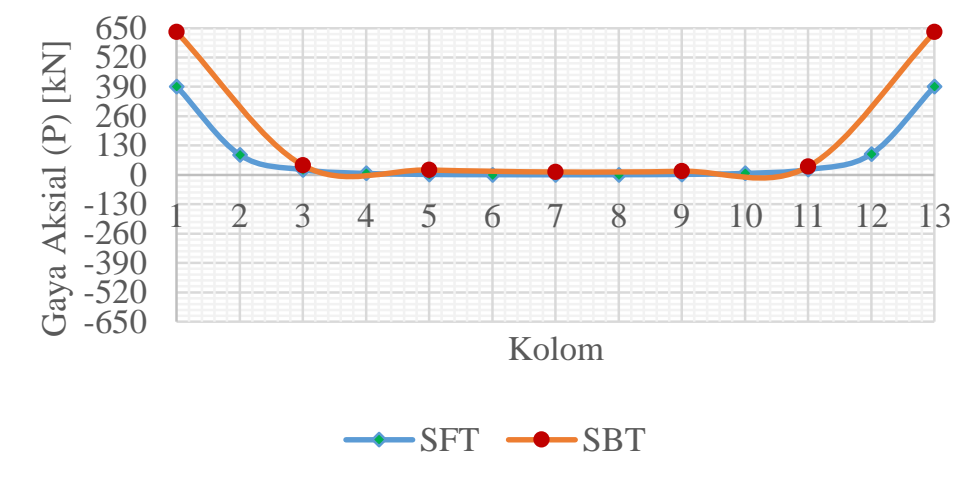

Gambar 13. Komparasi Distribusi Gaya Aksial Model SFT dan SBT pada Potongan G

\section{Analisis Respons Spektrum}

Berdasarkan analisis linear respons spektrum sistem SFT dan sistem SBT, diperoleh hasil sebagai berikut.

1. Periode Struktur

Dari hasil analisis modal diperoleh periode struktur pada model dengan Sistem SFT sebesar 2,981 detik, periode ini bernilai lebih besar 41,06\% dari periode pada Sistem SBT (1,757 detik).

2. Simpangan Antar Lantai

Simpangan antar lantai pada arah X maupun Y dari suatu gedung bertingkat tidak boleh melebihi simpangan ijin sesuai persyaratan SNI 1726:2012. Karena denah yang digunakan simetris, respons yang dihasilan pada arah X maupun Y cenderung bernilai sama. Berdasarkan Gambar 14, peralihan pada Sistem SFT lebih besar dibandingkan 
dengan Sistem SBT. Oleh karena itu dapat disimpulkan bahwa berdasarkan parameter peralihan tiap lantai, model dengan Sistem SBT lebih baik. Peralihan tiap lantai erat kaitannya dengan simpangan antar lantai, di mana simpangan antar lantai merupakan perbedaan defleksi (peralihan) pada pusat massa di tingkat teratas dan terbawah dari lantai yang ditinjau. Berdasarkan respons simpangan antar lantai, model dengan Sistem SBT juga lebih baik.

Tabel 3. Simpangan antar lantai Sistem SFT

\begin{tabular}{|c|c|c|c|c|c|c|}
\hline \multirow{2}{*}{ Lantai } & $\mathbf{h}_{\mathbf{s x}}$ & $\boldsymbol{\delta}_{\mathbf{m a x}}$ & $\boldsymbol{\Delta}_{\mathbf{m a x}}$ & $\boldsymbol{\Delta}_{\mathbf{m a x}} \cdot \mathbf{C}_{\mathbf{d}} / \mathbf{I}_{\mathbf{e}}$ & $\begin{array}{c}\boldsymbol{\Delta}_{\mathbf{a}} \\
(\mathbf{m})\end{array}$ & $\mathbf{C e k}$ \\
\hline 12 & $\mathbf{m})$ & $(\mathbf{m m})$ & $(\mathbf{m m})$ & $(\mathbf{m m})$ & 80 & Ok \\
\hline 11 & 4 & 21.82 & 0.48 & 2.65 & 80 & Ok \\
\hline 10 & 4 & 21.41 & 0.75 & 4.1 & 80 & Ok \\
\hline 9 & 4 & 20.78 & 1.02 & 5.63 & 80 & Ok \\
\hline 8 & 4 & 19.9 & 1.27 & 6.97 & 80 & Ok \\
\hline 7 & 4 & 17.42 & 1.67 & 9.19 & 80 & Ok \\
\hline 6 & 4 & 15.86 & 1.84 & 10.1 & 80 & Ok \\
\hline 5 & 4 & 14.11 & 2 & 10.98 & 80 & Ok \\
\hline 4 & 4 & 12.17 & 2.17 & 11.91 & 80 & Ok \\
\hline 3 & 4 & 10.04 & 2.39 & 13.15 & 80 & Ok \\
\hline 2 & 4 & 7.66 & 2.98 & 16.38 & 80 & Ok \\
\hline 1 & 4 & 4.68 & 4.68 & 25.73 & 80 & Ok \\
\hline Dasar & 4 & 0 & 0 & 0 & 80 & Ok \\
\hline & & & & & & \\
\hline
\end{tabular}

Tabel 4. Simpangan antar lantai Sistem SBT

\begin{tabular}{|c|c|c|c|c|c|c|}
\hline \multirow{2}{*}{ Lantai } & $\mathbf{h}_{\mathbf{s x}}$ & $\boldsymbol{\delta}_{\mathbf{m a x}}$ & $\boldsymbol{\Delta}_{\mathbf{m a x}}$ & $\boldsymbol{\Delta}_{\mathbf{m a x}} \cdot \mathbf{C}_{\mathbf{d}} / \mathbf{I}_{\mathbf{e}}$ & $\boldsymbol{\Delta}_{\mathbf{a}}$ & $\mathbf{C}$ \\
\cline { 2 - 7 } & $(\mathbf{m})$ & $\mathbf{( m m )}$ & $\mathbf{( m m )}$ & $(\mathbf{m m})$ & $(\mathbf{m m})$ & \\
\hline 12 & 4 & 17.32 & 0.15 & 0.73 & 80 & Ok \\
\hline 11 & 4 & 17.21 & 0.72 & 3.61 & 80 & Ok \\
\hline 10 & 4 & 16.57 & 0.87 & 4.34 & 80 & Ok \\
\hline 9 & 4 & 15.79 & 1.32 & 6.58 & 80 & Ok \\
\hline 8 & 4 & 14.56 & 1.4 & 6.98 & 80 & Ok \\
\hline 7 & 4 & 13.26 & 1.7 & 8.48 & 80 & Ok \\
\hline 6 & 4 & 11.63 & 1.67 & 8.33 & 80 & Ok \\
\hline 5 & 4 & 10.05 & 1.85 & 9.25 & 80 & Ok \\
\hline 4 & 4 & 8.23 & 1.87 & 9.35 & 80 & Ok \\
\hline 3 & 4 & 6.4 & 1.98 & 9.9 & 80 & Ok \\
\hline 2 & 4 & 4.43 & 1.93 & 9.63 & 80 & Ok \\
\hline 1 & 4 & 2.51 & 2.51 & 12.56 & 80 & Ok \\
\hline Das ar & 4 & 0 & 0 & 0 & 80 & Ok \\
\hline
\end{tabular}



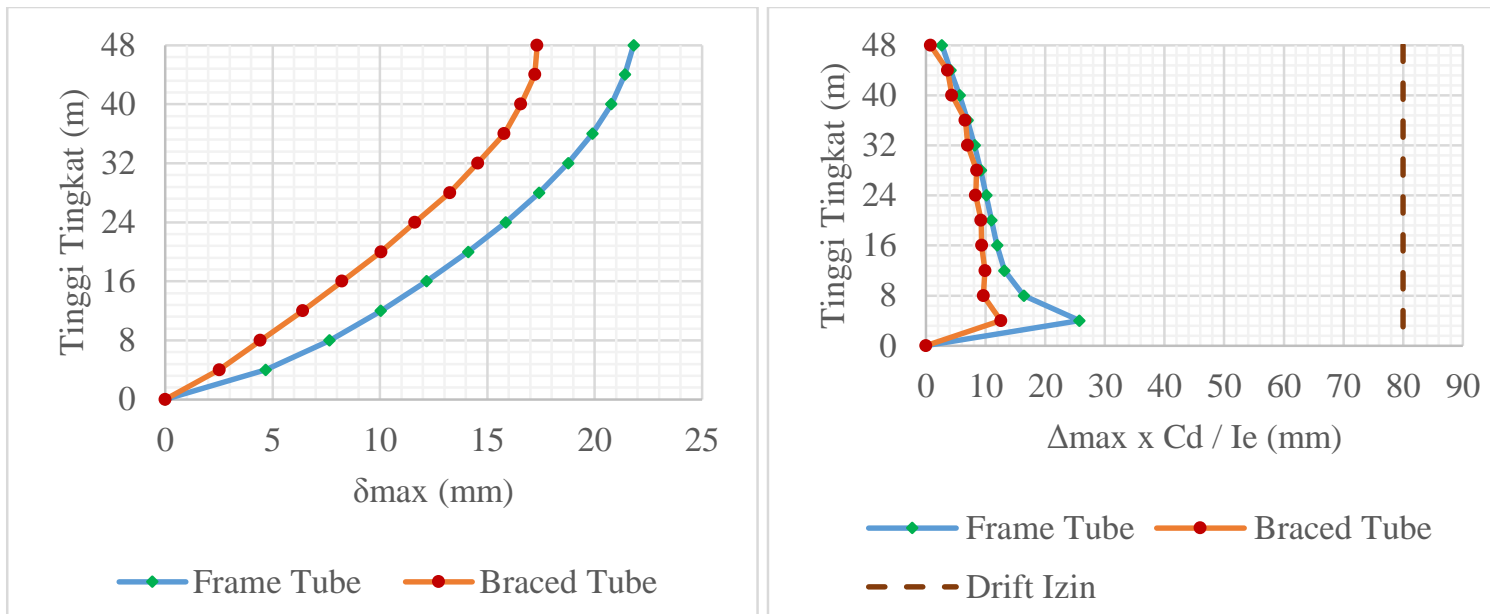

Gambar 14. Perbandingan Peralihan dan Simpangan Antar Lantai

3. Gaya Geser Tingkat

Semakin rendah elevasi tingkat, nilai gaya geser tingkat cenderung akan semakin besar, hal ini dikarenakan terdapat akumulasi gaya geser dari tingkat di atasnya. Semakin besar kekakuan suatu tingkat maka semakin besar juga gaya geser yang terjadi pada tingkat tersebut. Gaya geser tingkat pada kedua sistem dapat dilihat pada Gambar 15.

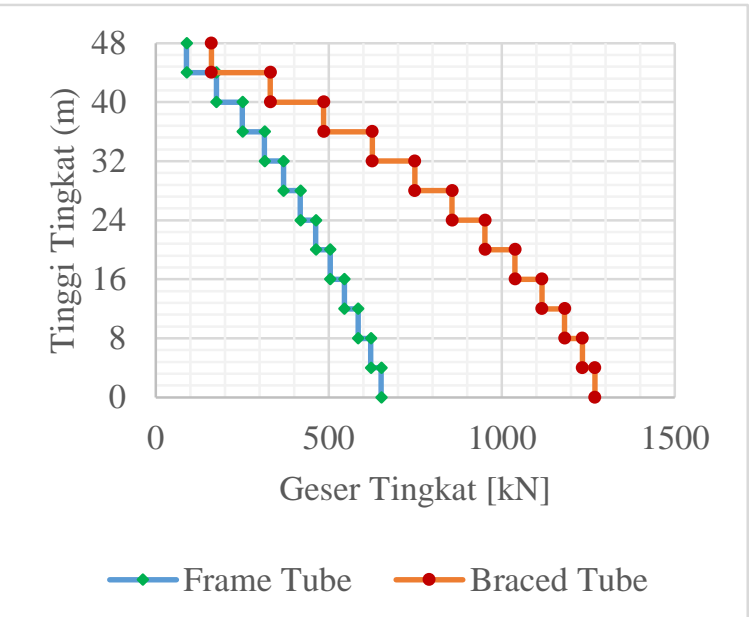

Gambar 15. Perbandingan Gaya Geser Tingkat Analisis Respons Spektrum

Berdarkan Gambar 15, dapat disimpulkan bahwa gaya geser model SBT memiliki nilai yang lebih besar dibandingkan dengan Sistem SFT. Hal ini berkaitan dengan kekakuan tingkat pada Sistem SBT yang lebih besar dibandingkan Sistem SFT.

\section{Analisis Riwayat Waktu}

Sendi plastis yang terjadi pada elemen ditinjau sesuai dengan arah datangnya gempa dan lokasi saat pertama kali sendi plastis terbentuk. Indikator warna dari sendi plastis sesuai dengan Gambar 4. Sendi plastis yang terjadi pada sistem SFT dan sistem SBT dapat dilihat pada Gambar 16 sampai dengan Gambar 21.

Dari hasil analisis, dapat disimpulkan bahwa elemen struktur yang pertama kali mengalami kelelehan adalah elemen spandrel pada Sistem SFT dan elemen breising pada Sistem SBT. Dapat disimpulkan mekanisme sendi plastis sesuai dengan yang direncanakan untuk kedua sistem struktur. Berikut merupakan waktu terjadinya sendi plastis pertama pada kedua sistem struktur. 


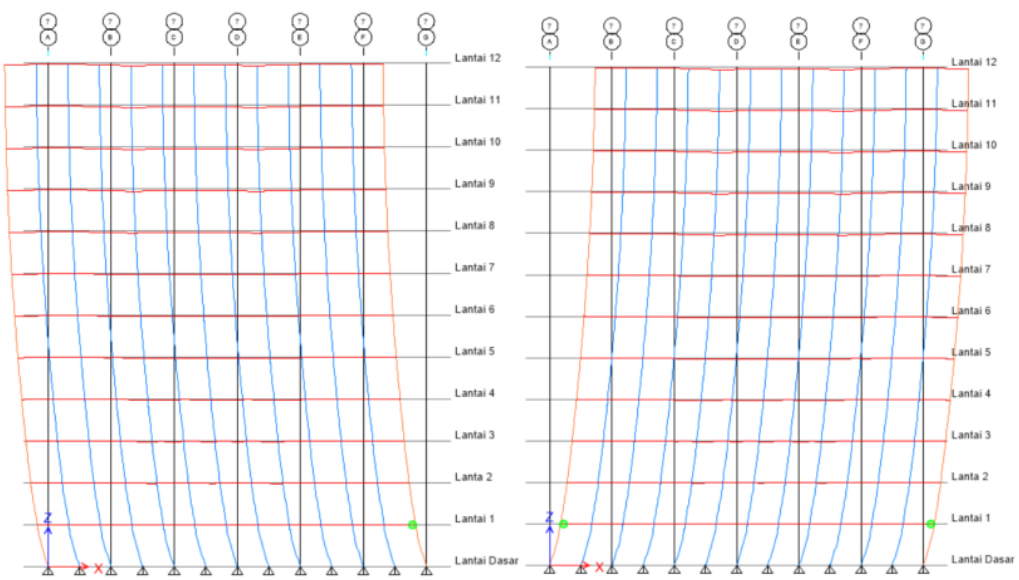

(a)

(b)

Gambar 16. Sendi Plastis pada Model SFT (El-Centro 1940) (a) Pertama (B) Terakhir

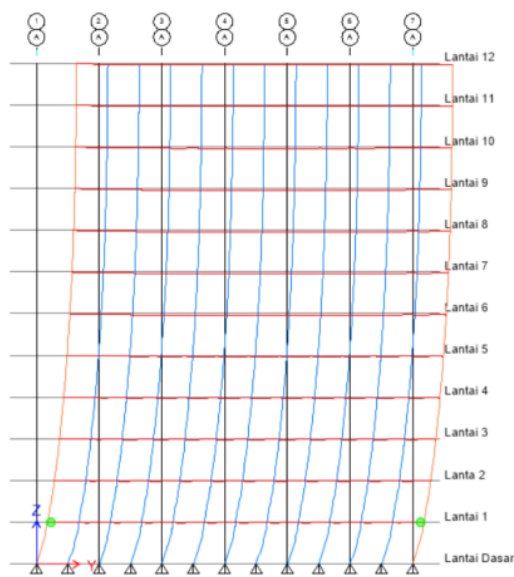

(a)

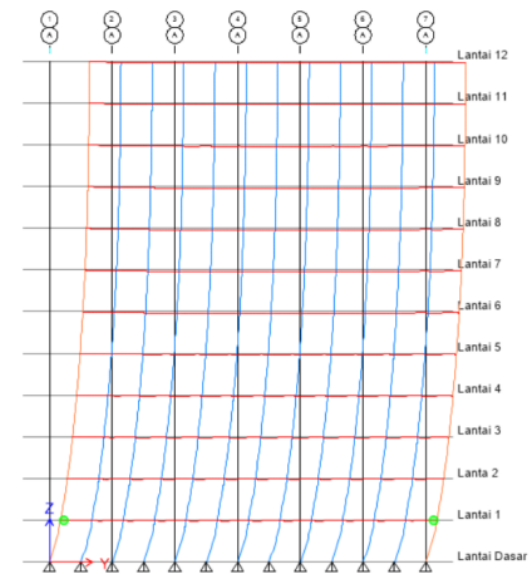

(b)

Gambar 17. Sendi Plastis pada Model SFT (Kobe 1995) (a) Pertama (B) Terakhir

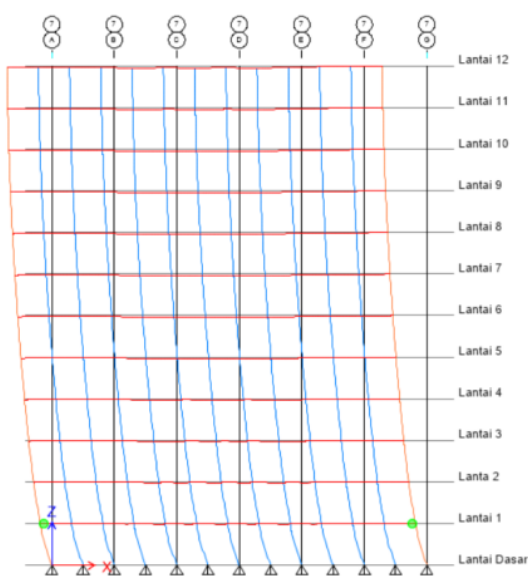

(a)

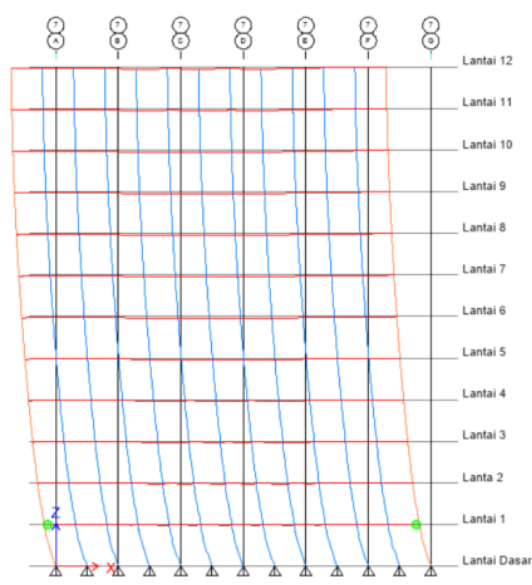

(b)

Gambar 18. Sendi Plastis pada Model SFT (Denpasar 1979) (a) Pertama (B) Terakhir 
(e)ISSN 2615-1847 (p)ISSN 2615-1839

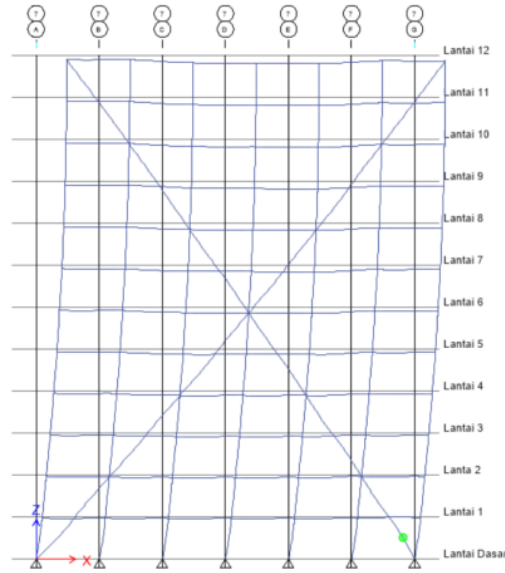

(a)

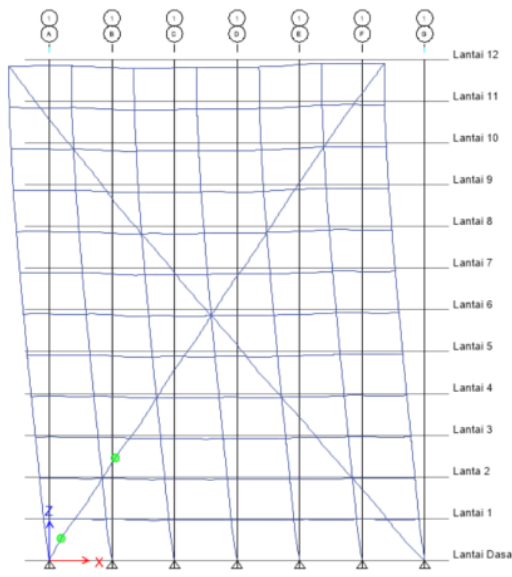

(b)

Gambar 19. Sendi Plastis pada Model SBT (El-Centro 1940) (a) Pertama (B) Terakhir

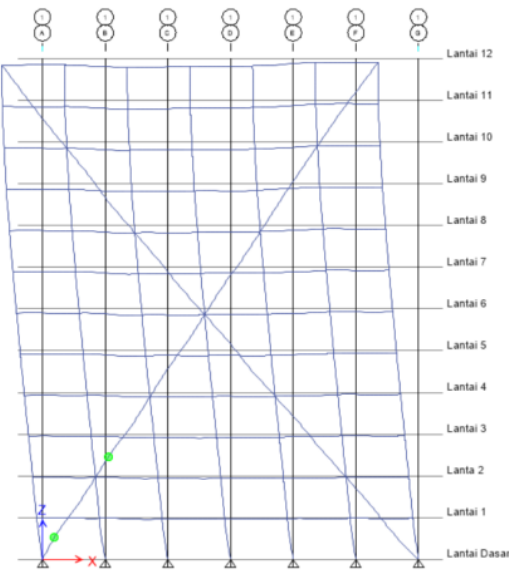

(a)

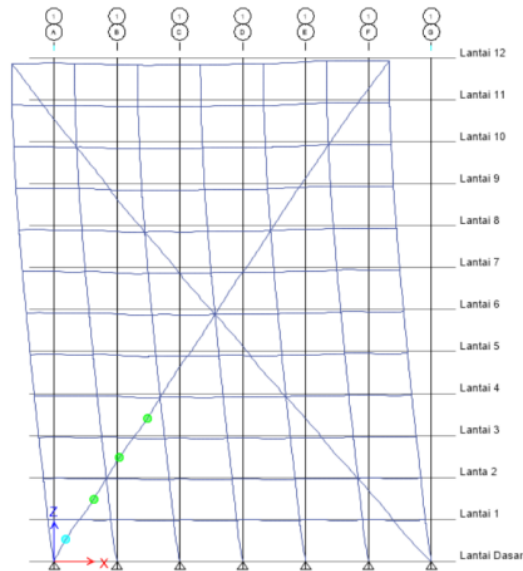

(b)

Gambar 20. Sendi Plastis pada Model SBT (Kobe 1995) (a) Pertama (B) Terakhir

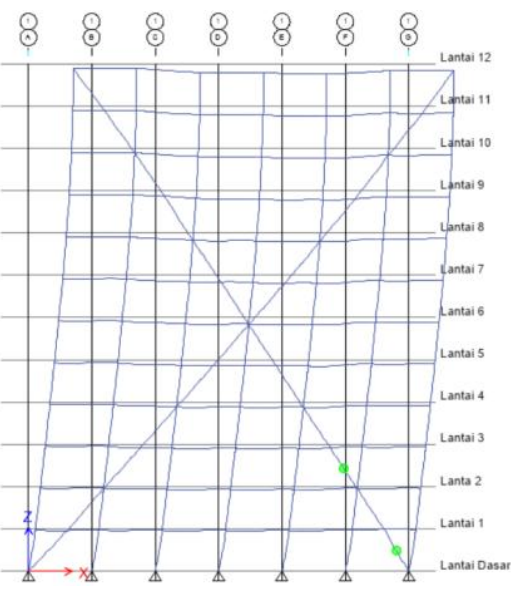

(a)

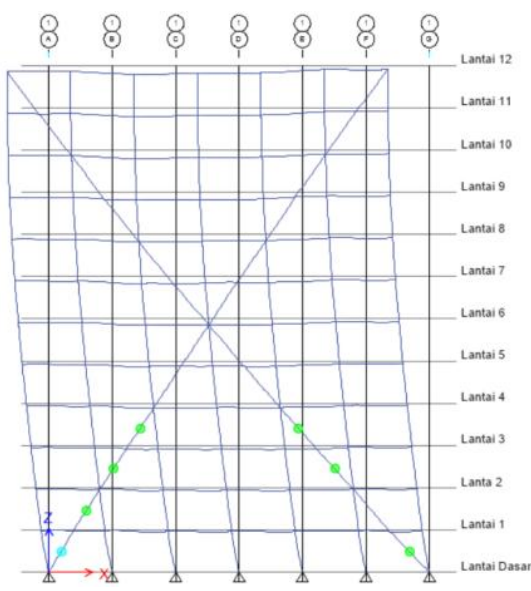

(b)

Gambar 21. Sendi plastis pada model SBT (Denpasar 1979) (a) Pertama (b) Terakhir

Tabel 5. Waktu Terjadi Sendi Plastis Pertama

\begin{tabular}{|l|c|c|c|}
\hline \multirow{2}{*}{ Sistem Struktur } & \multicolumn{3}{c}{ Waktu Terjadi Sendi Plas tis Pertama (detik) } \\
\cline { 2 - 4 } & El-Centro 1940 & Denpasar 1979 & Kobe 1995 \\
\hline Steel Frame Tube & 7.3 & 12.8 & 6.3 \\
\hline Steel Braced Tube & 4.9 & 7.8 & 5.8 \\
\hline
\end{tabular}


Model dengan Sistem SBT memiliki waktu terjadi sendi plastis pertama yang lebih cepat dari Sistem SFT. Hal ini karena breising mengalami kelelehan terlebih dahulu dibandingkan dengan spandrel. Kedua model tidak mengalami keruntuhan setelah rekaman percepatan gempa diberikan, hal ini ditandai dengan tidak terbentuknya sendi plastis pada elemen kolom.

Dilakukan analisis perbandingan peralihan tiap lantai dan simpangan antar lantai pada kedua sistem struktur dengan tiga rekaman gempa yang terjadi. Peralihan tiap lantai kedua sistem dapat dilihat pada Tabel 6.

Hasil yang diperoleh menunjukkan bahwa peralihan tiap lantai pada Sistem SFT akibat ketiga rekaman percepatan gempa cenderung memiliki nilai yang sama. Sedangkan peralihan tiap lantai terbesar pada Sistem SBT terjadi akibat rekaman gempa El-Centro 1940. Hasil analisis ini dapat dilihat pada Gambar 22.

Apabila dilakukan komparasi antara kedua sistem, dapat dilihat bahwa peralihan tiap lantai pada Sistem SFT bernilai lebih besar dibandingkan dengan Sistem SBT. Peralihan tiap lantai yang diperoleh dari analisis inelastik riwayat waktu menghasilkan kesimpulan yang sama dengan analisis elastik respons spektrum. Begitu pula dengan simpangan antar lantai yang diperoleh dari kedua sistem.

Tabel 6. Komparasi Peralihan Tiap Lantai

\begin{tabular}{|c|c|c|c|c|c|c|}
\hline \multirow{2}{*}{ Lantai } & \multicolumn{7}{|c|}{$\boldsymbol{\delta}(\mathbf{m m})$} \\
\cline { 2 - 7 } & \multicolumn{3}{|c|}{ Steel Frame Tube } & \multicolumn{3}{c|}{ Steel Braced Tube } \\
\cline { 2 - 7 } & $\begin{array}{c}\text { Denpas ar } \\
\mathbf{1 9 7 9}\end{array}$ & Kobe 1995 & $\begin{array}{c}\text { E Centro } \\
\mathbf{1 9 4 0}\end{array}$ & $\begin{array}{c}\text { Denpas ar } \\
\mathbf{1 9 7 9}\end{array}$ & Kobe 1995 & $\begin{array}{c}\text { E Centro } \\
\mathbf{1 9 4 0}\end{array}$ \\
\hline 12 & 210.5 & 200.26 & 202.74 & 82.67 & 98.1 & 98.9 \\
\hline 11 & 206.79 & 196.07 & 199.73 & 82.22 & 97.41 & 98.53 \\
\hline 10 & 200.93 & 189.51 & 194.97 & 79 & 93.69 & 95.61 \\
\hline 9 & 192.52 & 180.45 & 188.08 & 75.09 & 89.3 & 91.96 \\
\hline 8 & 181.58 & 170.61 & 178.97 & 68.94 & 82.37 & 86.11 \\
\hline 7 & 168.51 & 160.05 & 167.55 & 62.34 & 74.87 & 79.97 \\
\hline 6 & 156.51 & 149.36 & 153.86 & 54.18 & 65.74 & 72.51 \\
\hline 5 & 142.39 & 136.27 & 138.03 & 46.23 & 56.88 & 65.52 \\
\hline 4 & 125.97 & 121.28 & 120.63 & 37.37 & 47.19 & 58.41 \\
\hline 2 & 106.94 & 103.77 & 101.16 & 28.03 & 36.67 & 51.85 \\
\hline 1 & 84.36 & 82.28 & 78.83 & 18.75 & 25.57 & 43.18 \\
\hline Das ar & 53.3 & 52.12 & 49.36 & 11.06 & 14.97 & 28.41 \\
\hline
\end{tabular}

Batas simpangan antar lantai ijin untuk analisis inelastik nonlinear tidak boleh melebihi 1,25 dari batas simpangan antar lantai ijin analisis elastik $\left(\Delta_{a}\right) . \Delta_{a}$ pada skripsi ini adalah 80 $\mathrm{mm}$, sehingga batas $1,25 \Delta_{a}$ bernilai $100 \mathrm{~mm}$. 

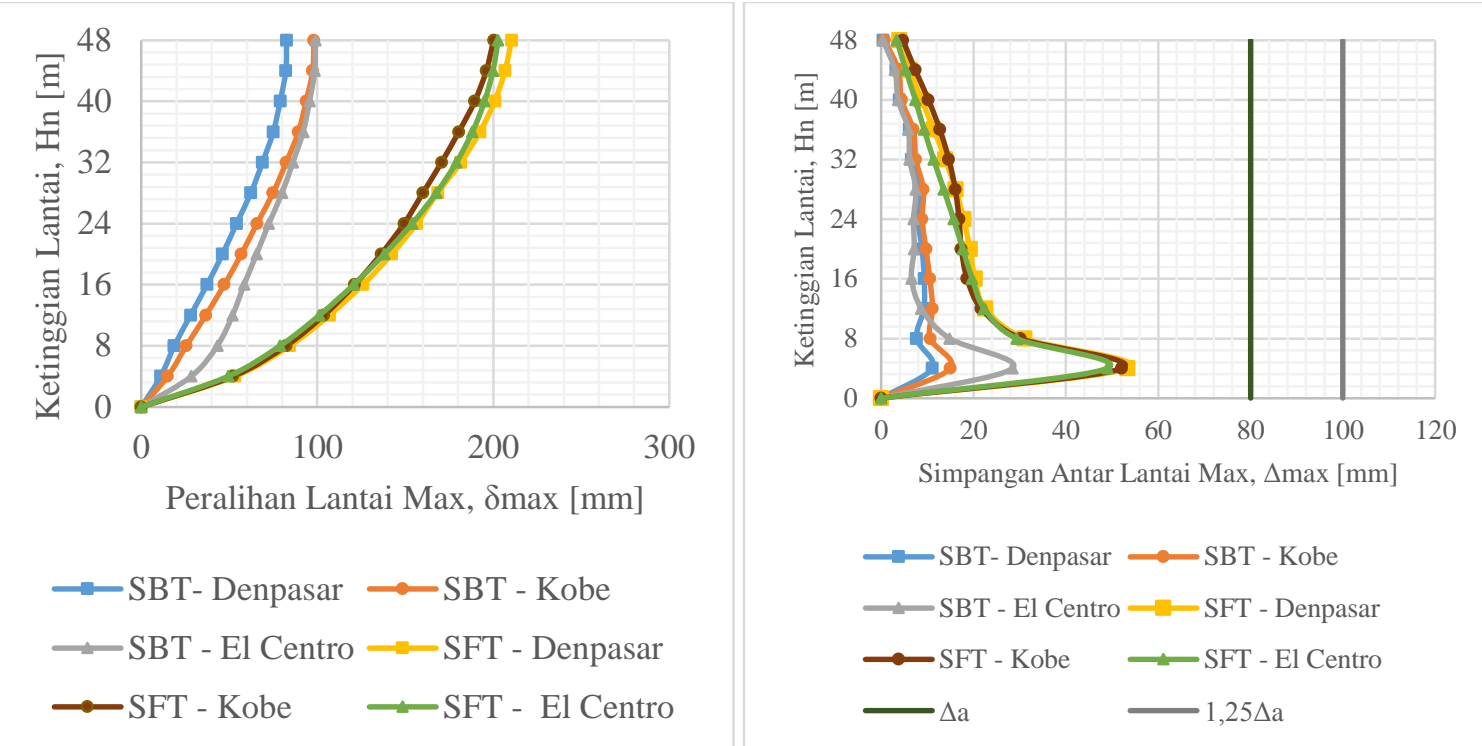

Gambar 22. Komparasi Peralihan Lantai dan Simpangan Antara Lantai Maksimum

\section{Tingkat Kinerja Struktur}

Berdasarkan Tabel 9, dapat diketahui bahwa tingkat kinerja struktur pada model dengan Sistem SFT dan model dengan Sistem SBT untuk percepatan gempa El-Centro 1940, Denpasar 1979, dan Kobe 1995 berada pada tingkat Immediately Occupancy (IO). Oleh karena itu, dapat disimpulkan melalui hasil analisis nonlinear riwayat waktu struktur gedung untuk kedua model dapat berfungsi kembali selama proses perbaikan dan tidak menimbulkan korban jiwa.

Tabel 7. Simpangan Lantai Atap Maksimum

\begin{tabular}{|c|c|c|c|c|}
\hline \multirow{2}{*}{ Gempa } & \multicolumn{2}{|c|}{ Steel Frame Tube } & \multicolumn{2}{c|}{ Steel Braced Tube } \\
\cline { 2 - 5 } & $\boldsymbol{\delta}_{\mathbf{x}}$ & $\boldsymbol{\delta}_{\mathbf{y}}$ & $\boldsymbol{\delta}_{\mathbf{x}}$ & $\boldsymbol{\delta}_{\mathbf{y}}$ \\
\cline { 2 - 5 } & $(\mathbf{m m})$ & $(\mathbf{m m})$ & $(\mathbf{m m})$ & $(\mathbf{m m})$ \\
\hline Denpas ar 1979 & 210.5 & 209.41 & 82.67 & 85.52 \\
\hline Kobe 1995 & 200.26 & 208.98 & 98.1 & 95.41 \\
\hline El Centro 1940 & 202.74 & 202.72 & 98.9 & 103.7 \\
\hline
\end{tabular}

Tabel 8. Roof Drift Ratio

\begin{tabular}{|c|c|c|c|c|}
\hline \multirow{2}{*}{ Gempa } & \multicolumn{2}{|c|}{ Steel Frame Tube } & \multicolumn{2}{c|}{ Steel Braced Tube } \\
\cline { 2 - 5 } & Arah X & Arah Y & Arah X & Arah Y \\
\hline Denpasar 1979 & 0.00439 & 0.00436 & 0.00172 & 0.00178 \\
\hline Kobe 1995 & 0.00417 & 0.00435 & 0.00204 & 0.00199 \\
\hline El Centro 1940 & 0.00422 & 0.00422 & 0.00206 & 0.00216 \\
\hline
\end{tabular}

Tabel 9. Tingkat Kinerja Struktur

\begin{tabular}{|c|c|c|c|c|}
\hline \multirow{2}{*}{ Gempa } & \multicolumn{2}{|c|}{ Steel Frame Tube } & \multicolumn{2}{c|}{ Steel Braced Tube } \\
\cline { 2 - 5 } & Arah X & Arah Y & Arah X & Arah Y \\
\hline Denpasar 1979 & IO & IO & IO & IO \\
\hline Kobe 1995 & IO & IO & IO & IO \\
\hline El Centro 1940 & IO & IO & IO & IO \\
\hline
\end{tabular}




\section{KESIMPULAN}

Berdasarkan studi yang telah dilakukan terhadap gedung dengan Sistem Steel Frame Tube (SFT) dan Sistem Steel Braced Tube (SBT) dengan melakukan analisis shearlag, respons spektrum, dan riwayat waktu, dapat diperoleh beberapa simpulan sebagai berikut.

1. Ketinggian lantai mempengaruhi besar gaya aksial pada kolom perimeter sudut. Semakin tinggi lantai, maka gaya aksial pada kolom perimeter sudut menjadi semakin kecil dan mendekati besar gaya aksial pada kolom perimeter lain. Hal ini menandakan, seiring bertambah ketinggian suatu lantai maka efek shear lag yang terjadi semakin berkurang.

2. Karena kekakuan struktur pada model dengan Sistem SBT lebih besar dibandingkan model dengan Sistem SFT, saat kondisi elastik maupun inelastik peralihan tiap lantai dan simpangan antar lantai maksimum gedung dengan Sistem SBT lebih kecil daripada Sistem SFT. Oleh karena itu pada kedua kondisi tersebut, Sistem SBT lebih baik.

3. Berdasarkan analisis respons spektrum diperoleh simpulan sebagai berikut.

a. Periode struktur pada model dengan Sistem SFT sebesar 2,981 detik, sedangkan periode struktur pada model dengan Sistem SBT sebesar 1,757 detik.

b. Gaya geser tingkat pada model dengan Sistem SBT lebih besar dari Sistem SFT.

4. Berdasarkan analisis riwayat waktu diperoleh simpulan sebagai berikut.

a. Sendi plastis pada Sistem SFT terjadi pada spandrel dan sendi plastis pada Sistem SBT terjadi pada breising untuk ketiga rekaman percepatan gempa

b. Pada ketiga rekaman percepatan gempa, sendi plastis pertama kali terjadi pada model dengan Sistem SBT.

c. Pada model dengan Sistem SFT, peralihan tiap lantai dan simpangan antar lantai cenderung bernilai sama untuk ketiga rekaman percepatan gempa. Sedangkan pada model dengan Sistem SBT, peralihan tiap lantai dan simpangan antar lantai maksimum terjadi akibat rekaman gempa El-Centro 1940.

d. Tingkat kinerja model untuk Sistem SFT dan Sistem SBT adalah Immediately Occupancy (IO).

\section{DAFTAR PUSTAKA}

AISC 341-16. American Institute of Steel Construction 314-16 on Seismic Provisions for Structural Steel Buildings.

AISC 360-16. American Institute of Steel Construction 360-16 on Specification for Structural Steel Buildings.

Alipour, A., \& Zareian, F. (2008). "Study Rayleigh Damping in Structures; Uncertanties and Treatments". The $14^{\text {th }}$ World Conference on Earthquake Engineering.

Arifin, M., Fransisca, L., \& Sagara, A. (2019). "Studi Perbandingan Gedung dengan Iregularitas Horizontal Menggunakan Base Isolation dan Fixed Base". Jurnal Manajemen Aset Infrastruktur \& Fasilitas, Vol. 3, No. 2, September 2019.

ASCE 41-17. American Society of Civil Engineers 41-17 on Seismic Evaluation and Retrofit of Existing Buildings.

FEMA 356:2000. Federal Emergency Management Agency 356:2020 on Prestandard and Commentary for The Seismic Rehabilitation of Buildings.

Jasinda, Clarissa (2018). Studi Perbandingan Perilaku Inelastik Struktur Gedung Baja Turbular Terbreis Konsentris dan Eksentris Tipe Inverted-V. Skripsi Pendidikan Sarjana. Jurusan Teknik Sipil. Universitas Katolik Parahyangan.

Reddy, B.V.S., \& Eadukondalu, M. (2018). "Study of Lateral Structural Systems in Tall Buildings". International Journal of Applied Engineering Research, Vol. 13, No. 3.

SNI 1726:2012. Standar Nasional Indonesia SNI 1726:2012 tentang Tata Cara Perencanaan Ketahanan Gempa untuk Struktur Bangunan Gedung dan Non Gedung. 
SNI 1727:2013. Standar Nasional Indonesia SNI 1727:2013 tentang Beban Minimum untuk Perancangan Bangunan Gedung dan Struktur Lain.

Steeger, K. (2010). Implementation of a User-defines Time Integration in FEAP: Wilson- $\theta$. Department of Civil and Environmental Engineering. University of California. Berkeley. Suprayitno, H. \& Soemitro, R.A.A. (2018). "Preliminary Reflexion on Basic Principle of Infrastructure Asset Management”. Jurnal Manajemen Aset Infrastruktur \& Fasilitas, Vol. 2, No. 1, Maret 2018.

Taranath, S. B. (2012). Structural Analysis and Design of Tall Buildings Steel and Composite Construction. CRC Press Taylor \& Francis Group.

Taranath, S. B. (2017). Tall Building Design: Steel, Concrete, and Composite Systems. CRC Press Taylor \& Francis Group. 